\title{
Subretinal Injection: A Review on the Novel Route of Therapeutic Delivery for Vitreoretinal Diseases
}

\author{
Yingqian Peng Luosheng Tang Yedi Zhou \\ Department of Ophthalmology, The Second Xiangya Hospital, Central South University, Changsha, China
}

\section{Keywords}

Subretinal injection - Drug delivery · Intravitreal injection . Vitreoretinal disease

\begin{abstract}
Compared to intravitreal injection, subretinal injection has more direct effects on the targeting cells in the subretinal space, which provides a new therapeutic method for vitreoretinal diseases, especially when gene therapy and/or cell therapy is involved. To date, subretinal delivery has been widely applied by scientists and clinicians as a more precise and efficient route of ocular drug delivery for gene therapies and cell therapies including stem cells in many degenerative vitreoretinal diseases, such as retinitis pigmentosa, age-related macular degeneration, and Leber's congenital amaurosis. However, clinicians should be aware of adverse events and possible complications when performing subretinal delivery. In the present review, the subretinal injection used in vitreoretinal diseases for basic research and clinical trials is summarized and described. Different methods of subretinal delivery, as well as its benefits and challenges, are also briefly introduced.

(c) 2017 S. Karger AG, Basel
\end{abstract}

\section{Introduction}

Intraocular drug delivery is commonly used for the treatment of vitreoretinal diseases $[1,2]$. In particular, anti-VEGF therapy consisting of intravitreal injection has been performed worldwide for the treatment of many vision loss diseases, such as age-related macular degeneration (AMD), diabetic macular edema, proliferative diabetic retinopathy, and retinopathy of prematurity, in targeting ocular neovascularization and vascular occlusions [3-7]. The treatment of intravitreal delivery is useful because it provides several benefits such as direct delivery of drugs into the vitreous and retina and the simplicity of achievement of this procedure by the medical doctors. However, this therapeutic method might also lead to adverse events and complications, such as intraocular inflammation, retinal detachment, ocular hemorrhage, and cataract, as well as patient incompliance $[2,8]$. Besides, because of the thickness and structure of the retina, intravitreal injection has a limited target effect in the posterior segment of the eye (e.g., retinal pigment epithelium [RPE] cells and photoreceptors).

Recently, subretinal delivery has becoming increasingly popular in both scientific research and clinical applications, and it has been regarded as one of the best strategies for gene therapy through subretinal local delivery of the

Yedi Zhou, MD, PhD

Department of Ophthalmology, The Second Xiangya Hospital Central South University, No. 139 Middle Renmin Road

Changsha, Hunan 410011 (China)

E-Mail zhouyedi@csu.edu.cn 
viral vector, which has been performed effectively for retinitis pigmentosa (RP) and Leber's congenital amaurosis (LCA) [9-12]. Also, it has been reported that subretinal injection of macrophages leads to pathological fibrosis, which could be used for assessment of advanced AMD in mice $[13,14]$. Subretinal delivery can also be used for transplantation of stem cells in ocular degenerative diseases, which has been reported in in vivo studies and aimed towards clinical applications [15-18].

Compared to intravitreal injection, subretinal delivery has a direct effect on the resident cells and tissues in the subretinal space, while a higher stability and proficiency of operators are required. In this review, an overview of the benefits and challenges of subretinal delivery as a therapeutic option in vitroretinal diseases is presented. Various advances and developments in subretinal delivery are also emphasized.

\section{Overview of Subretinal Injection}

Drug delivery in the eye is more challenging because of various ocular barriers compared to delivery of drugs to other parts of the body. Many of these barriers are considered to protect the eye from toxicants anatomically and physiologically, but at the same time they also makes drug delivery in the eye a challenging task for scientists and clinicians [19]. In general, ocular drug delivery includes 2 major parts: anterior segment drug delivery and posterior ocular delivery. For drug delivery in vitreoretinal diseases, like diabetic retinopathy and AMD, which are the most prevalent diseases affecting the posterior segment of the eye [20], an efficient way to deliver therapeutic material to the back of the eye is required. There are many unique barriers in the eye preventing optimal drug delivery into the retina, including cillary nonpigmented epithelium (bloodaqueous barrier), RPE (outer blood-retinal barrier), and retinal vascular endothelium (inner blood-retinal barrier) [21]. Consequentially, the most convenient and patientcompliant route of drug administration - i.e., topical eye drops - is hardly effective for disease of the posterior segment of the eye, although it has been widely used in eye diseases, particularly for the treatment of anterior segment diseases [20]. Delivery of drug and gene or cell therapy to the back of the eye becomes an even more challenging task. In order to make drug delivery more efficient for vitreoretinal diseases, 2 major pathways have been developed to: intravitreal and subrentinal drug delivery. Intravitreal drug delivery has been a dominant method in treating vitreoretinal diseases for the last few decades, and it comprises direct intravitreal injection and intravitreal implantable device technology as well as bioerodible and nonbioerodible intravitreal implantable devices [22]. Via this effective technique, clinicians can administer drugs such as anti-VEGF [23-27] and steroids [28-31], among others, or gene therapy such as vectors containing specific genes [32-34], stem cells $[35,36]$, etc., directly into the back of the eye to increase drug concentration in the vitreous and the retina. However, the complications associated with this method have emerged, gaining increasing attention from clinicians. In spite of the common risks and complications caused by intravitreal injection itself, such as bleeding, retinal holes, and cataract, a high intraocular eye pressure is the most common one for steroids $[37,38]$, and it can lead to damage of the optic nerve and result in secondary glaucoma. Besides, endophthalmitis has been gradually recognized as a major complication of intravitreal anti-VEGF drug delivery [39, 40]. In addition, some scientists have pointed out that some retinal degenerative diseases mainly affect RPE cells and photoreceptors, such as AMD and RP. Thus, there should be another way to deliver drugs more directly to these cells. Under this circumstances, subretinal drug delivery has emerged and become increasingly popular for the treatment of vitreoretinal diseases.

The subretinal space, by definition, is the space between RPE cells and photoreceptors. In the subretinal space, injected material comes into direct contact with the plasma membrane of the photoreceptor, and RPE cells and subretinal blebs $[9,41]$. This makes it an excellent site for drug delivery [42], especially in patients with visionthreatening disorders attributable to mutations in photoreceptor and/or RPE genes and retinal degenerative diseases.

In early times, subretinal injection was applied in a model of hereditary retinal degeneration (dystrophic RCG rats) to transplant human fetal RPE cells, and this provided the first indication that transplantation of human fetal RPE cells subretinally in rats was able to rescue photoreceptor cells [43]. Bindewald et al. [44] reported in patients with AMD the transplantation of RPE following $\mathrm{CNV}$ removal. They injected both heterologous and homologous RPE cell suspensions into the subretinal space and demonstrated preservation of foveal neurosensory functions [44]. For the past 10 years, subretinal drug delivery has been widely used in gene therapy and cell therapy experimentally and clinically for retinal degenerative diseases, such as AMD, RP, LCA, and Stargardt disease. The application of subretinal injections in both animal models and clinical trials is summarized in Figure 1. 


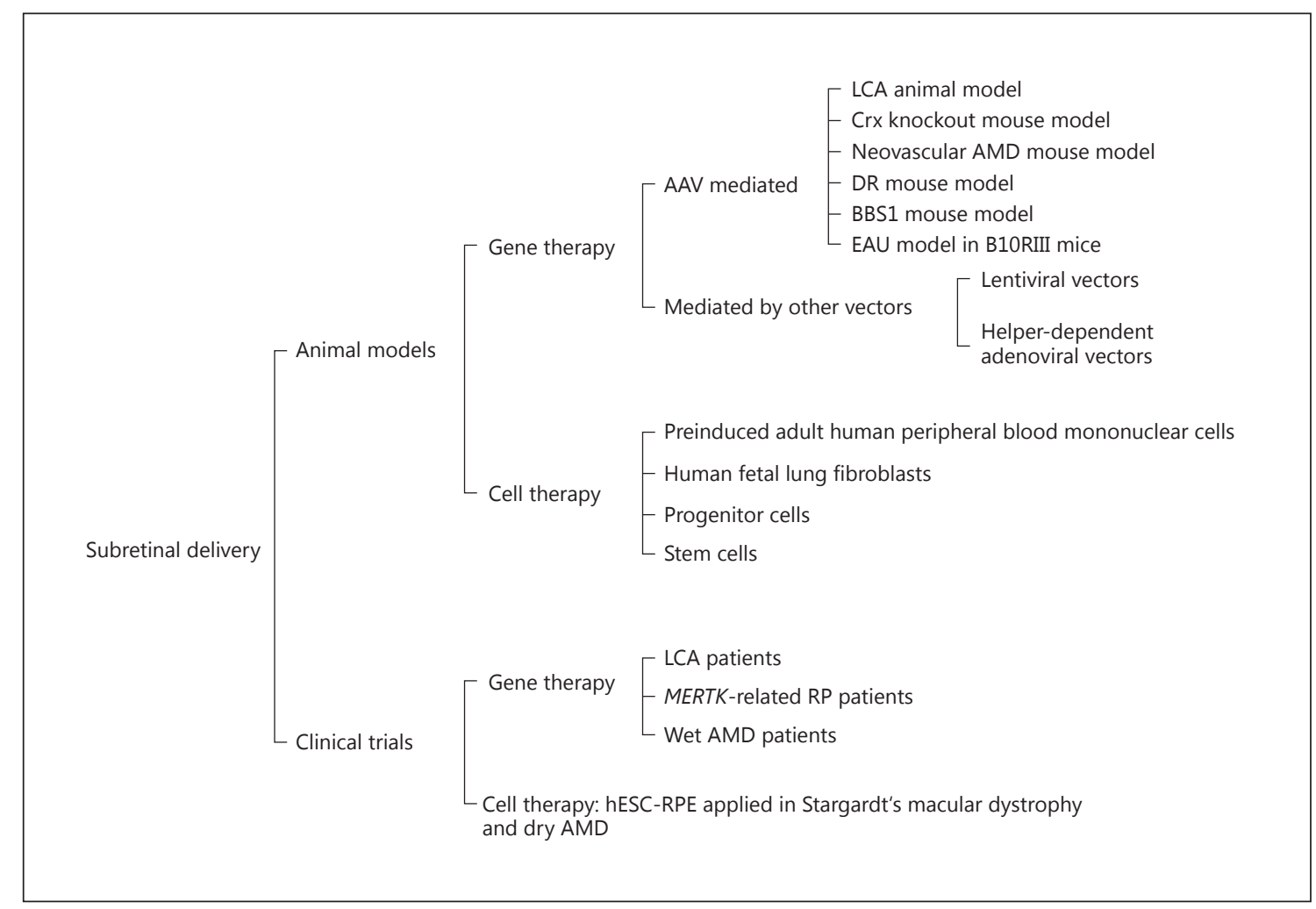

Fig. 1. Applications of subretinal injections in both animal models and clinical trials. AAV, adeno-associated virus; LCA, Leber's congenital amaurosis; AMD, age-related macular degeneration; hESC-RPE, human embryonic stem cell-derived retinal epithelium; DR, diabetic retinopathy; BBS1, Bardet-Biedl syndrome type 1; EAU, experimental anotoimmune uvoretinitis.

\section{Application of Subretinal Injection in Animal Models}

\section{Gene Therapy}

The eye, in particular, is an attractive target for gene therapy for the following reasons: (1) insignificant immune responses will occur, (2) only small amounts of viral vectors might be needed to achieve therapeutic effects, (3) it allows localized treatment without intravenous delivery, and (4) the effects, efficacy, and safety can be easily observed and monitored by noninvasive technologies such as electroretinogram and optic coherence tomography $[45,46]$.

Adeno-associated virus (AAV) is a small, nonpathogenic dependovirus that has shown significant promise for safe and stable expression of a genetic payload in the retina [47], and it has emerged as the vector of choice for gene delivery to the retina. To date, AAV has been used as treatment in an increasing number of animal models of inherited retinal degeneration, and subretinal injection has been shown to be the most common and efficient way

Subretinal Injection for Therapeutic Delivery to deliver AAV with target genes. Among all of the serotypes of AAV, AAV2 is well characterized and widely used.

In an LCA animal model, subretinal injection of recombinant AAV 2/5-OPTIRPE65 improved retinal function against retinal degeneration in Rpe65 knockout mice [48], and long-term transduction of RPE cells and photoreceptors in rats and nonhuman primates was observed [49]. AAV2 delivery of the RPE65 gene subretinally to the retina showed restoration of vision, rescuing the numbers of remaining photoreceptors both in young and old RPE65-mutant/deficient dogs [50, 51]. Watanabe et al. [52] reported on their subretinal delivery of 7 AAV serotypes into the developing mouse retina and demonstrated the possibility of gene replacement for the developmental disorder and subsequent degeneration of retinal photoreceptors induced by the absence of Crx. In retinal degeneration 11 (rd11) mice, which carry a mutation in the Lpcatl gene, subretinal injection of the AAV8 (Y733F)smCBA-Lpcat1 vector was given on different postnatal

Ophthalmic Res 2017;58:217-226 DOI: $10.1159 / 000479157$ 
days and long-term preservation of electroretinogram responses as well as preservation of the retinal structure was observed, indicating that subretinal gene therapy in the LPCAT1 deficiency mouse model was successful [53].

In a neovascular AMD mouse model, subretinal AAV2 localization and plasmid protein expression was verified in the RPE and/or choroid of mice treated with all AAV2 constructs, and those authors suggested that subretinal injection of AAV2.COMP-Ang1 (AAV-mediated gene therapy with cartilage oligomeric matrix protein angiopoietin-1) has the potential to be an alternative and supplementary option to anti-VEGF agents for the long-term amelioration of neovascular AMD [54].

In a diabetic retinopathy mouse model, subretinal delivery of AAV2-mediated human erythropoietin (AAV2CMV-hEPO) gene therapy was reported to be safe, and it could exert long-term protective effects on diabetic retinas [55].

In a Bardet-Biedl syndrome type 1 (BBS1) mouse model, in which severe retinal degeneration is one of the characteristics, BBSome formation and rhodopsin localization were rescued by subretinal delivery of AAV-Bbs1 (AAV vectors containing the $B b s 1$ gene), and a trend toward improved electroretinogram results was shown [56].

In addition to AAV, other vectors, such as helper-dependent adenoviral vectors, which are considered to have a huge potential to improve the success rate of gene therapy achieved by the adeno-associated viral vector due to their large cloning capacity, have also been reported to complete gene delivery subretinally [57]. Lentiviral vectors are promising tools for treating retinal degenerative diseases such as AMD. Ikeda et al. [10] showed that retinal expression was stable in nonhuman primates via subretinal injection using simian immunodeficiency virus from African green monkeys (SIVagm)-based lentiviral vectors. Murakami et al. [58] reported that a newly developed lentiviral vector pesudotyped with Sendai viral envelope proteins (SeV-F/HN-SIV) achieved fast, efficient, and stable gene transfer in the mouse RPE when injected subretinally.

Based on the animal models described above, subretinal delivery of gene therapy has mostly focused on retinal degenerative diseases and gene deficiency diseases; with the target gene delivered subretinally by vectors, retina function can be restored to some extent.

However, not limited to retinal degenerative and gene deficiency diseases, AAV2-mediated subretinal drug delivery has also been used in experimental anotoimmune uvoretinitis models in B10RIII mice [59-61].
As gene therapy via subretinal injection is a localized delivery to the subretinal space and the vectors are relatively safe, subretinal injection has been considered to be nonsystemic toxic, well tolerated, and effective in animal models [50, 62-64].

\section{Cell Therapy}

Another important application of subretinal delivery is cell therapy. The unique anatomy of the subretinal space makes it an efficient means of delivering cells to either target RPE cells or photoreceptors or both. In the past several years, various types of cells have been given subretinally in animal models for the treatment of retinal degeneration diseases. Pre-induced adult human peripheral blood mononuclear cells survived and migrated in retinal degeneration slow (rds) mice 3 months after subretinal transplantation [65]. In rats, photoreceptor degeneration can be prevented by subretinal transplantation of human fetal lung fibroblasts expressing the ciliary neurotrophic factor gene [66], and laser-induced choroidal neovascularization can be inhibited by subretinal transplantation of RPE overexpressing fibulin-5 [67]. Of all of the cell types, progenitor cells and stem cells, such as human neural progenitor cells [68], human retinal progenitor cells [69], progenitor cells from the porcine neural retina [70], forebrain progenitor cells [71], brain-derived precursor cells [72], human embryonic stem cell-derived retinal progenitors [73], human RPE stem cells [74], human bone marrow mesenchymal stem cells [75], and rat mesenchymal stem cells [76], are the most popular when given subretinally for cell replacement therapy for retinal degeneration. All these cells are considered to have the capability to survive and migrate into retinal layers and restore retina function or induce cell regeneration in different types of retinal cells when delivered via the subretinal route.

Cell therapy via subretinal delivery in animal models, especially using human embryonic stem cell-derived retinal pigment epithelium (hESC-RPE) cells, has been considered safe and nontoxic. It have been reported to be feasible and safe after subretinal implantation, with neither cell migration from the scaffold nor development of ocular or systemic tumors [77]. It therefore constitutes a promising start for human studies [78].

\section{Application of Subretinal Injection in Clinical Trials}

Since experiments and studies in animal models have demonstrated the feasibility and safety of gene and cell therapy via subretinal injections, a basis for clinical trials
220

Ophthalmic Res 2017;58:217-226 DOI: $10.1159 / 000479157$
Peng/Tang/Zhou 
has been built. There are several ongoing clinical trials using subretinal drug delivery-conducted gene or cell therapy to treat retinal degenerative diseases.

\section{Gene Therapy}

As early as in 2008, two clinical trails showed that delivery of a recombinant AAV carrying RPE65 complementary DNA subretinally is effective and safe as a gene therapy for LCA $[79,80]$. In 2009 , another clinical trial with 12 patients with RPE65-associated LCA confirmed the safety, extent, and stability of vision improvement in all patients who underwent subretinal injection of AAV2 containing a gene encoding a protein needed for the isomerohydrolase activity of the RPE, and it supported the application of AAV-mediated gene therapy for the treatment of inherited retinal diseases [81]. In recent years, long-term clinic trails have shown that LCA2 gene therapy provides stable visual and retinal function improvement after subretinal treatment [12]; the short-term results of a phase I trial demonstrated that both vectorrelated serious adverse events and systemic toxicities were not detected with subretinal injection of the AAV vector. Moreover, increased visual sensitivity was self-reported in all patients for treated eyes compared to control eyes, and this was remarkably noticeable under reduced ambient light conditions [82].

A clinical trial in MERTK-related RP patients showed that subretinal injection of rAAV2-VMD2-hMERTK, when administered carefully, may have resulted in clinical improvement in a subset of patients and it was not associated with major side effects [11]. In wet AMD patients, gene therapy with recombinant adeno-associated vectors delivered subretinally has been reported to be safe and well tolerated, and it can be used as a potential longterm treatment option for wet AMD [83, 84].

\section{Cell Therapy}

Cell therapy via the subretinal space has been developed for clinical applications. Schwartz et al. [85] reported the possibility of hESC-RPE to treat patients with Stargardt's macular dystrophy and dry AMD and provided preliminary data. Recently, 2 phase I/II studies with a length of 4 years, involving 18 patients with dry AMD or Stargardt's disease, demonstrated the possibility of safe implantation of hESC-RPE subretinally in an attempt to rescue photoreceptors and vision [86].

Although cell therapy via the subretinal space has been considered to be relatively safe when the right techniques are used and it is performed carefully, complications should still be a big concern when applying this technique

Subretinal Injection for Therapeutic Delivery in a large number of patients. Recurrent retinal detachment with proliferative vitreoretinopathy was reported in a 60-year-old man with Stargardt's macular dystrophy after subretinal injection of autologous bone marrow-derived stem cells, but after retina reattachment visual acuity may be improved and return to the baseline [87].

\section{Subretinal Delivery versus Intravitreal Injection?}

It has been discussed that intravitreal injection provides greater direct drug concentrations to the vitreous and retina, which are commonly used for delivery of antiVEGF agents, such as bevacizumab and ranibizumab in wet AMD patients $[88,89]$. It is also useful for the delivery of triamcinolone acetonide, as well as antivirus drugs for ocular infections [90, 91]. However, regarding this delivery route, short-term complications including retinal detachment, endophthalmitis, and hemorrhage have to be noted $[88,91]$. Moreover, intravitreal injection has a weak effect on some other drugs targeting the cells in subretinal spaces (RPE cells, for instance) because of the barriers (e.g., the internal limiting membrane) between the retina and RPE cells $[92,93]$. It might also represent the injection of an unnecessarily high dose of the drug into the vitreous. Compared to intravitreal injection, subretinal delivery of viral vectors is thought to be the most efficient transduction of neurosensory retina and RPE [92]. It provides a direct route with more precise localization via a minimally invasive injection. With subretinal delivery, a lower dose is needed for accurate targeting of cells in the subretinal space.

The majority of studies and applications have focused on gene therapy using vectors, or stem cell therapy [94]. Gene therapy via vectors has been performed in studies for applications in inherited retinal diseases, such as RP and LCA [95-97]. Virus vectors might lead to acute toxicity and a cellular immune response, and the period of transfection gene expression is limited; it also has risks, i.e., potential safety hazards [98]. Unlike the vitreous cavity, the subretinal space is a closed anatomic area, which also has a greater immune privilege, and it could be a better and safer position for the delivery of virus vectors directly to RPE cells $[99,100]$. Moreover, nonviral gene therapy has also been developed for ocular therapeutic purposes, which provides a wider range of applications, easier utilization, and lower costs, and it might increase efficacy and genomic safety [101].

Similar to gene therapy, stem cells have also been used for retinal degeneration diseases, and subretinal delivery

Ophthalmic Res 2017;58:217-226

DOI: $10.1159 / 000479157$ 


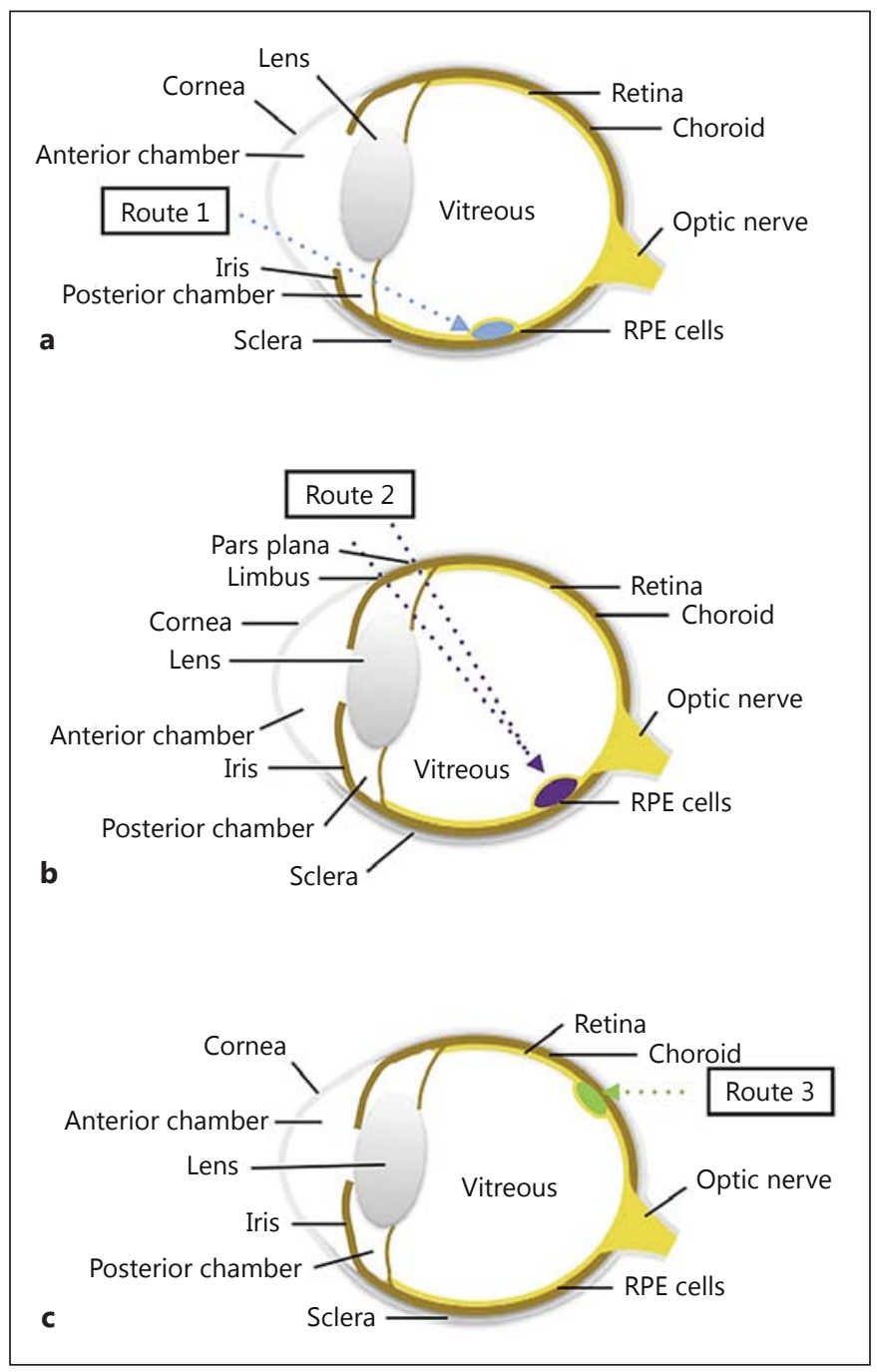

Fig. 2. Approaches of subretinal injections in animal experiments. a Transcorneal route through the pupil, passing the lens, vitreous, and retina. $\mathbf{b}$ Transscleral route entering the pars plana or limbus areas, crossing through the vitreous and the opposite side of retina into the subretinal space. c Transscleral route through the choroid and Bruch's membrane without penetrating the retina. RPE, retinal pigment epithelium.

provides a direct, effective, and safe route to specific targeting cells $[85,102]$. Hu et al. [103] reported a new technique of subretinal implantation of ultrathin substrates containing stem cell-derived RPE cells, which showed a useful approach for stem cells and retinal transplantation studies.

Hillenkamp et al. [104] reported that in submacular hemorrhage patients with pars plana vitrectomy, subretinal delivery of tissue plasminogen activator (rtPA) with intravitreal injection of gas, rather than intravitreal injection of rtPA and gas, was more effective in displacement of submacular hemorrhage. Subretinal injection leads to more frequent complications, such as retinal detachment, vitreous hemorrhage, recurrence of submacular hemorrhage, and postoperative development of CNV. Thus, a careful patient selection is necessary in order to ensure fewer complications after subretinal delivery.

\section{Approaches for Subretinal Injection}

Basically, approaches for subretinal injections can be divided into 3 groups: (1) a transcorneal route through the pupil, passing the lens, vitreous, and retina $[105,106]$; (2) a transscleral route entering the pars plana or limbus areas, crossing through the vitreous and the opposite side of retina into the subretinal space $[9,107,108]$; and (3) a transscleral route through the choroid and Bruch's membrane without penetrating the retina [109-111] (Fig. 2). Regardless of the route chosen, all of the routes are effective for delivery of virus, viral particles, liposomes, plasmids, drugs, and formulations; they are also useful in collecting the contents of the subretinal space [41].

Scientists have demonstrated different approaches to complete subretinal injections as the anatomy of the eyeball varies slightly according to the species and age. Usually this procedure is performed under direct visualization using an operating microscope, and a bleb formation should be observed as a sign of success of the procedure.

Since subretinal delivery is being increasingly used both in animal models and in clinical patients, new variations of this technique are emerged constantly. Mouse is the most common animal model for a large number of the inherited eye diseases which are perfectly suitable for gene therapy, and subretinal injections in mice are better studied and protocols of subretinal injections vary from group to group $[94,112]$. There are also new approaches for other relatively larger animal models. A new platform device was reported to be helpful in relation to the monolayer of hESC-RPE implantation in retinas of rats [103]. A new subretinal injection device (RetinaJect Subretinal Cannula; SurModics, Inc., Eden Prairie, MN, USA) was evaluated and found to be superior to the conventional subretinal injection device when performing subretinal injection in dogs [113].

In the clinical procedures described above, the subretinal injections of the hESC-RPE reported by Schwartz et al. $[85,86]$ were preformed along the site of a pars plana vitrectomy, and the injection sites were carefully chosen on the basis of optical coherence tomography results. Sites with native, albeit compromised, RPE and similarly
Peng/Tang/Zhou 
compromised overlaying photoreceptors were thought to be the optimal injection spots for transplantation.

In sum, in order to achieve successful delivery of target genes or cells for the treatment of retinal degeneration disease via subretinal injections, suitable approaches should be considered depending on the species, age, available devices and the surgical skills of the physician.

\section{Conclusion}

In summary, subretinal injection is a novel route of drug and/or cell delivery for vitreoretinal diseases. In particular, subretinal injection provides better and safer ef- fects in gene and cell therapies, and might be considered as a potential delivery option for personalized medical care with specific targets in the subretinal space.

\section{Acknowledgments}

This review article was supported in part by the National Natural Science Foundation of China (No. 81371036)

\section{Disclosure Statement}

The authors declare no competing financial interests related to this submission.

\section{References}

1 Yasukawa T, Ogura Y, Tabata Y, Kimura H, Wiedemann P, Honda Y: Drug delivery systems for vitreoretinal diseases. Prog Retin Eye Res 2004;23:253-281.

2 Gaudana R, Ananthula HK, Parenky A, Mitra AK: Ocular drug delivery. AAPS J 2010;12: 348-360.

3 Heier JS, Brown DM, Chong V, Korobelnik JF, Kaiser PK, Nguyen QD, Kirchhof B, Ho A, Ogura Y, Yancopoulos GD, Stahl N, Vitti R, Berliner AJ, Soo Y, Anderesi M, Groetzbach G, Sommerauer B, Sandbrink R, Simader C, Schmidt-Erfurth U; VIEW 1 and VIEW 2 Study Groups: Intravitreal aflibercept (VEGF trap-eye) in wet age-related macular degeneration. Ophthalmology 2012;119:25372548.

4 Korobelnik JF, Do DV, Schmidt-Erfurth U, Boyer DS, Holz FG, Heier JS, Midena E, Kaiser PK, Terasaki H, Marcus DM, Nguyen QD, Jaffe GJ, Slakter JS, Simader C, Soo Y, Schmelter T, Yancopoulos GD, Stahl N, Vitti R, Berliner AJ, Zeitz O, Metzig C, Brown DM: Intravitreal aflibercept for diabetic macular edema. Ophthalmology 2014;121:2247-2254.

5 Simo R, Sundstrom JM, Antonetti DA: Ocular Anti-VEGF therapy for diabetic retinopathy: the role of VEGF in the pathogenesis of diabetic retinopathy. Diabetes Care 2014;37: 893-899.

6 Osaadon P, Fagan XJ, Lifshitz T, Levy J: A review of anti-VEGF agents for proliferative diabetic retinopathy. Eye (Lond) 2014;28:510520.

7 Chen SN, Lian I, Hwang YC, Chen YH, Chang YC, Lee KH, Chuang CC, Wu WC: Intravitreal anti-vascular endothelial growth factor treatment for retinopathy of prematurity: comparison between ranibizumab and bevacizumab. Retina 2015;35:667-674.
8 Falavarjani KG, Nguyen QD: Adverse events and complications associated with intravitreal injection of anti-VEGF agents: a review of literature. Eye (Lond) 2013;27:787-794.

9 Muhlfriedel R, Michalakis S, Garcia Garrido M, Biel M, Seeliger MW: Optimized technique for subretinal injections in mice. Methods Mol Biol 2013;935:343-349.

10 Ikeda Y, Yonemitsu Y, Miyazaki M, Kohno R, Murakami Y, Murata T, Tabata T, Ueda Y, Ono F, Suzuki T, Ageyama N, Terao K, Hasegawa M, Sueishi K, Ishibashi T: Stable retinal gene expression in nonhuman primates via subretinal injection of SIVagmbased lentiviral vectors. Hum Gene Ther 2009;20:573-579.

11 Ghazi NG, Abboud EB, Nowilaty SR, Alkuraya H, Alhommadi A, Cai H, Hou R, Deng WT, Boye SL, Almaghamsi A, Al Saikhan F, AlDhibi H, Birch D, Chung C, Colak D, LaVail MM, Vollrath D, Erger K, Wang W, Conlon T, Zhang K, Hauswirth W, Alkuraya FS: Treatment of retinitis pigmentosa due to MERTK mutations by ocular subretinal injection of adeno-associated virus gene vector: results of a phase I trial. Hum Genet 2016;135: 327-343.

12 Testa F, Maguire AM, Rossi S, Pierce EA, Melillo P, Marshall K, Banfi S, Surace EM, Sun J, Acerra C, Wright JF, Wellman J, High KA, Auricchio A, Bennett J, Simonelli F: Threeyear follow-up after unilateral subretinal delivery of adeno-associated virus in patients with Leber congenital amaurosis type 2. Ophthalmology 2013;120:1283-1291.

13 Jo YJ, Sonoda KH, Oshima Y, Takeda A, Kohno R, Yamada J, Hamuro J, Yang Y, Notomi S, Hisatomi T, Ishibashi T: Establishment of a new animal model of focal subretinal fibrosis that resembles disciform lesion in advanced age-related macular degeneration. Invest Ophthalmol Vis Sci 2011;52:6089-6095.
14 Yang Y, Takeda A, Yoshimura T, Oshima Y, Sonoda KH, Ishibashi T: IL-10 is significantly involved in HSP70-regulation of experimental subretinal fibrosis. PLoS One 2013;8: e80288.

15 Shirai H, Mandai M, Matsushita K, Kuwahara A, Yonemura S, Nakano T, Assawachananont J, Kimura T, Saito K, Terasaki H, Eiraku M, Sasai Y, Takahashi M: Transplantation of human embryonic stem cell-derived retinal tissue in two primate models of retinal degeneration. Proc Natl Acad Sci USA 2016;113: E81-90.

16 Kanemura H, Go MJ, Shikamura M, Nishishita N, Sakai N, Kamao H, Mandai M, Morinaga C, Takahashi M, Kawamata S: Tumorigenicity studies of induced pluripotent stem cell (iPSC)-derived retinal pigment epithelium (RPE) for the treatment of age-related macular degeneration. PLoS One 2014;9: e85336.

17 Sugita S, Iwasaki Y, Makabe K, Kamao H, Mandai M, Shiina T, Ogasawara K, Hirami Y, Kurimoto Y, Takahashi M: Successful transplantation of retinal pigment epithelial cells from MHC homozygote iPSCs in MHCmatched models. Stem Cell Rep 2016;7:635648.

18 Kamao H, Mandai M, Okamoto S, Sakai N, Suga A, Sugita S, Kiryu J, Takahashi M: Characterization of human induced pluripotent stem cell-derived retinal pigment epithelium cell sheets aiming for clinical application. Stem Cell Rep 2014;2:205-218.

19 Yavuz B, Kompella UB: Ocular drug delivery. Handb Exp Pharmacol 2017;242:57-93.

20 Patel A, Cholkar K, Agrahari V, Mitra AK: Ocular drug delivery systems: an overview. World J Pharmacol 2013;2:47-64. 
21 Short BG: Safety evaluation of ocular drug delivery formulations: techniques and practical considerations. Toxicol Pathol 2008;36:4962.

22 Choonara YE, Pillay V, Danckwerts MP, Carmichael TR, du Toit LC: A review of implantable intravitreal drug delivery technologies for the treatment of posterior segment eye diseases. J Pharm Sci 2010;99:2219-2239.

23 Hwang DJ, Kim YW, Woo SJ, Park KH: Comparison of systemic adverse events associated with intravitreal anti-VEGF injection: ranibizumab versus bevacizumab. J Korean Med Sci 2012;27:1580-1585.

24 Vujosevic S, Torresin T, Bini S, Convento E, Pilotto E, Parrozzani R, Midena E: Imaging retinal inflammatory biomarkers after intravitreal steroid and anti-VEGF treatment in diabetic macular oedema. Acta Ophthalmol 2017;95:464-471.

25 Giocanti-Auregan A, Tadayoni R, Grenet T, Fajnkuchen F, Nghiem-Buffet S, DelahayeMazza C, Quentel G, Cohen SY: Estimation of the need for bilateral intravitreal anti-VEGF injections in clinical practice. BMC Ophthalmol 2016;16:142.

26 Bek T, Jorgensen CM: The systemic blood pressure and oxygen saturation in retinal arterioles predict the effect of intravitreal antiVEGF treatment on diabetic maculopathy. Invest Ophthalmol Vis Sci 2016;57:54295434.

27 Gemenetzi M, Lotery AJ, Patel PJ: Risk of geographic atrophy in age-related macular degeneration patients treated with intravitreal anti-VEGF agents. Eye (Lond) 2017;31:1-9.

28 Chatziralli I, Nicholson L, Sivaprasad S, Hykin P: Intravitreal steroid and anti-vascular endothelial growth agents for the management of retinal vein occlusion: evidence from randomized trials. Expert Opin Biol Ther 2015;15:1685-1697.

29 Gunther J, Ip M: Intravitreal steroid versus macular laser for treatment of diabetic macular edema. Curr Diab Rep 2009;9:272-276.

30 Jonas JB, Rensch F: Intravitreal steroid slowrelease device replacing repeated intravitreal triamcinolone injections for sympathetic ophthalmia. Eur J Ophthalmol 2008;18:834836.

31 Logan SA, Weng CY, Carvounis PE: Intravitreal steroid implants in the management of retinal disease and uveitis. Int Ophthalmol Clin 2016;56:127-149.

32 Tracy CJ, Whiting RE, Pearce JW, Williamson BG, Vansteenkiste DP, Gillespie LE, Castaner LJ, Bryan JN, Coates JR, Jensen CA, Katz ML: Intravitreal implantation of TPP1-transduced stem cells delays retinal degeneration in canine CLN2 neuronal ceroid lipofuscinosis. Exp Eye Res 2016;152:77-87.

33 De Silva SR, Charbel Issa P, Singh MS, Lipinski DM, Barnea-Cramer AO, Walker NJ, Barnard AR, Hankins MW, MacLaren RE: Single residue AAV capsid mutation improves transduction of photoreceptors in the Abca4-/- mouse and bipolar cells in the rd 1 mouse and human retina ex vivo. Gene Ther 2016;23: 767-774.

34 Acland GM, Aguirre GD, Bennett J, Aleman TS, Cideciyan AV, Bennicelli J, Dejneka NS, Pearce-Kelling SE, Maguire AM, Palczewski K, Hauswirth WW, Jacobson SG: Long-term restoration of rod and cone vision by single dose rAAV-mediated gene transfer to the retina in a canine model of childhood blindness. Mol Ther 2005; 12:1072-1082.

35 Emre E, Yuksel N, Duruksu G, Pirhan D, Subasi C, Erman G, Karaoz E: Neuroprotective effects of intravitreally transplanted adipose tissue and bone marrow-derived mesenchymal stem cells in an experimental ocular hypertension model. Cytotherapy 2015;17:543559.

36 Flachsbarth K, Kruszewski K, Jung G, Jankowiak W, Riecken K, Wagenfeld L, Richard G, Fehse B, Bartsch U: Neural stem cell-based intraocular administration of ciliary neurotrophic factor attenuates the loss of axotomized ganglion cells in adult mice. Invest Ophthalmol Vis Sci 2014;55:7029-7039.

37 Bollinger KE, Smith SD: Prevalence and management of elevated intraocular pressure after placement of an intravitreal sustained-release steroid implant. Curr Opin Ophthalmol 2009; 20:99-103.

38 Fitzgerald JT, Saunders L, Ridge B, White AJ, Goldberg I, Clark B, Mills RA, Craig JE: Severe intraocular pressure response to periocular or intravitreal steroid treatment in Australia and New Zealand: data from the Australian and New Zealand Ophthalmic Surveillance Unit. Clin Exp Ophthalmol 2015;43:234-238.

39 Kanchanaranya N, Rojdamrongratana D, Piyasoonthorn P: Incidence of post-intravitreal anti-VEGF endophthalmitis at Thammasat University Hospital. J Med Assoc Thai 2015; 98:489-494.

40 Kuhicka-Trzaska A, Jedrychowska-Jamhorska JJ, Kulig-Stochmal A, Morawski K, Romanowska-Dixon B: (Endophthalmitis as a complication of intravitreal anti-VEGF therapy in patients with exudative age-related macular degeneration and degenerative myopia (in Polish). Klin Oczna 2015;117: 35-39.

41 Johnson CJ, Berglin L, Chrenek MA, Redmond TM, Boatright JH, Nickerson JM: Technical brief: subretinal injection and electroporation into adult mouse eyes. Mol Vis 2008;14:2211-2226.

42 Maia M, Kellner L, de Juan E Jr, Smith R, Farah ME, Margalit E, Lakhanpal RR, Grebe L, Au Eong KG, Humayun MS: Effects of indocyanine green injection on the retinal surface and into the subretinal space in rabbits. Retina 2004;24:80-91.

43 Little CW, Castillo B, DiLoreto DA, Cox C, Wyatt J, del Cerro C, del Cerro M: Transplantation of human fetal retinal pigment epithelium rescues photoreceptor cells from degeneration in the Royal College of Surgeons rat retina. Invest Ophthalmol Vis Sci 1996;37: 204-211.
44 Bindewald A, Roth F, Van Meurs J, Holz FG: Transplantation of retinal pigment pithelium (RPE) following CNV removal in patients with AMD. Techniques, results, outlook (in German). Ophthalmologe 2004;101:886-894.

45 Smith AJ, Bainbridge JW, Ali RR: Gene supplementation therapy for recessive forms of inherited retinal dystrophies. Gene Ther 2012;19:154-161.

46 Bainbridge JW, Tan MH, Ali RR: Gene therapy progress and prospects: the eye. Gene Ther 2006;13:1191-1197.

47 Day TP, Byrne LC, Schaffer DV, Flannery JG: Advances in AAV vector development for gene therapy in the retina. Adv Exp Med Biol 2014;801:687-693.

48 Georgiadis A, Duran Y, Ribeiro J, AbelleiraHervas L, Robbie SJ, Sunkel-Laing B, Fourali $\mathrm{S}$, Gonzalez-Cordero A, Cristante E, Michaelides M, Bainbridge JW, Smith AJ, Ali RR: Development of an optimized AAV2/5 gene therapy vector for Leber congenital amaurosis owing to defects in RPE65. Gene Ther 2016;23:857-862.

49 Weber M, Rabinowitz J, Provost N, Conrath H, Folliot S, Briot D, Cherel Y, Chenuaud P, Samulski J, Moullier P, Rolling F: Recombinant adeno-associated virus serotype 4 mediates unique and exclusive long-term transduction of retinal pigmented epithelium in rat, dog, and nonhuman primate after subretinal delivery. Mol Ther 2003;7:774-781.

50 Jacobson SG, Acland GM, Aguirre GD, Aleman TS, Schwartz SB, Cideciyan AV, Zeiss CJ, Komaromy AM, Kaushal S, Roman AJ, Windsor EA, Sumaroka A, Pearce-Kelling SE, Conlon TJ, Chiodo VA, Boye SL, Flotte TR, Maguire AM, Bennett J, Hauswirth WW: Safety of recombinant adeno-associated virus type 2 RPE65 vector delivered by ocular subretinal injection. Mol Ther 2006;13:1074-1084.

51 Annear MJ, Mowat FM, Bartoe JT, Querubin J, Azam SA, Basche M, Curran PG, Smith AJ, Bainbridge JW, Ali RR, Petersen-Jones SM: Successful gene therapy in older Rpe65-deficient dogs following subretinal injection of an adeno-associated vector expressing RPE65. Hum Gene Ther 2013;24:883-893.

52 Watanabe S, Sanuki R, Ueno S, Koyasu T, Hasegawa T, Furukawa T: Tropisms of AAV for subretinal delivery to the neonatal mouse retina and its application for in vivo rescue of developmental photoreceptor disorders. PLoS One 2013;8:e54146.

53 Dai X, Zhang H, Han J, He Y, Zhang Y, Qi Y, Pang JJ: Effects of subretinal gene transfer at different time points in a mouse model of retinal degeneration. PLoS One 2016;11: e0156542.

54 Lambert NG, Zhang X, Rai RR, Uehara H, Choi S, Carroll LS, Das SK, Cahoon JM, Kirk BH, Bentley BM, Ambati BK: Subretinal AAV2.COMP-Ang1 suppresses choroidal neovascularization and vascular endothelial growth factor in a murine model of age-related macular degeneration. Exp Eye Res 2016; 145:248-257. 
55 Xu H, Zhang L, Gu L, Lu L, Gao G, Li W, Xu G, Wang J, Gao F, Xu JY, Yao J, Wang F, Zhang J, $\mathrm{Xu}$ GT: Subretinal delivery of AAV2-mediated human erythropoietin gene is protective and safe in experimental diabetic retinopathy. Invest Ophthalmol Vis Sci 2014;55:1519-1530.

56 Seo S, Mullins RF, Dumitrescu AV, Bhattarai S, Gratie D, Wang K, Stone EM, Sheffield V, Drack AV: Subretinal gene therapy of mice with Bardet-Biedl syndrome type 1. Invest Ophthalmol Vis Sci 2013;54:6118-6132.

$57 \mathrm{Wu}$ L, Lam S, Cao H, Guan R, Duan R, van der Kooy D, Bremner R, Molday RS, Hu J: Subretinal gene delivery using helper-dependent adenoviral vectors. Cell Biosci 2011;1:15.

58 Murakami Y, Ikeda Y, Yonemitsu Y, Miyazaki $M$, Inoue $M$, Hasegawa $M$, Sueishi $K$, Ishibashi T: Inhibition of choroidal neovascularization via brief subretinal exposure to a newly developed lentiviral vector pseudotyped with Sendai viral envelope proteins. Hum Gene Ther 2010;21:199-209.

59 Tian L, Lei B, Shao J, Wei L, Kijlstra A, Yang P: AAV2-mediated combined subretinal delivery of IFN-alpha and IL-4 reduces the severity of experimental autoimmune uveoretinitis. PLoS One 2012;7:e37995.

60 Tian L, Yang P, Lei B, Shao J, Wang C, Xiang Q, Wei L, Peng Z, Kijlstra A: AAV2-mediated subretinal gene transfer of hIFN-alpha attenuates experimental autoimmune uveoretinitis in mice. PLoS One 2011;6:e19542.

61 Shao J, Tian L, Lei B, Wei L, Yang Y, Kijlstra A, Yang P: AAV2-mediated subretinal gene transfer of mIL-27p28 attenuates experimental autoimmune uveoretinitis in mice. PLoS One 2012;7:e37773.

62 Lai CM, Estcourt MJ, Himbeck RP, Lee SY, Yew-San Yeo I, Luu C, Loh BK, Lee MW, Barathi A, Villano J, Ang CL, van der Most RG, Constable IJ, Dismuke D, Samulski RJ, Degli-Esposti MA, Rakoczy EP: Preclinical safety evaluation of subretinal AAV2.sFlt-1 in non-human primates. Gene Ther 2012;19: 999-1009.

63 Amado D, Mingozzi F, Hui D, Bennicelli JL, Wei Z, Chen Y, Bote E, Grant RL, Golden JA, Narfstrom K, Syed NA, Orlin SE, High KA, Maguire AM, Bennett J: Safety and efficacy of subretinal readministration of a viral vector in large animals to treat congenital blindness. Sci Transl Med 2010;2:21ra16.

64 Barker SE, Broderick CA, Robbie SJ, Duran Y, Natkunarajah M, Buch P, Balaggan KS, MacLaren RE, Bainbridge JW, Smith AJ, Ali RR: Subretinal delivery of adeno-associated virus serotype 2 results in minimal immune responses that allow repeat vector administration in immunocompetent mice. J Gene Med 2009;11:486-497.

65 Peng Y, Zhang Y, Huang B, Luo Y, Zhang M, Li K, Li W, Wen W, Tang S: Survival and migration of pre-induced adult human peripheral blood mononuclear cells in retinal degeneration slow (rds) mice three months after subretinal transplantation. Curr Stem Cell Res Ther 2014;9:124-133.
66 Huang Q, Xu P, Xia X, Hu HH, Wang F, Li HM: Subretinal transplantation of human fetal lung fibroblasts expressed ciliary neurotrophic factor gene prevent photoreceptor degeneration in RCS rats (in Chinese). Zhonghua Yan Ke Za Zhi 2006;42:127-130.

67 Li F, Zeng Y, Xu H, Yin ZQ: Subretinal transplantation of retinal pigment epithelium overexpressing fibulin-5 inhibits laser-induced choroidal neovascularization in rats. Exp Eye Res 2015;136:78-85.

68 Jones MK, Lu B, Saghizadeh M, Wang S: Gene expression changes in the retina following subretinal injection of human neural progenitor cells into a rodent model for retinal degeneration. Mol Vis 2016;22:472-490.

69 Huang R, Baranov P, Lai K, Zhang X, Ge J, Young MJ: Functional and morphological analysis of the subretinal injection of human retinal progenitor cells under Cyclosporin A treatment. Mol Vis 2014;20:1271-1280.

70 Klassen H, Kiilgaard JF, Zahir T, Ziaeian B, Kirov I, Scherfig E, Warfvinge K, Young MJ: Progenitor cells from the porcine neural retina express photoreceptor markers after transplantation to the subretinal space of allorecipients. Stem Cells 2007;25:1222-1230.

71 Francis PJ, Wang S, Zhang Y, Brown A, Hwang T, McFarland TJ, Jeffrey BG, Lu B, Wright L, Appukuttan B, Wilson DJ, Stout JT, Neuringer M, Gamm DM, Lund RD: Subretinal transplantation of forebrain progenitor cells in nonhuman primates: survival and intact retinal function. Invest Ophthalmol Vis Sci 2009;50:3425-3431.

72 Wojciechowski AB, Englund U, Lundberg C, Warfvinge K: Long-term survival and glial differentiation of the brain-derived precursor cell line RN33B after subretinal transplantation to adult normal rats. Stem Cells 2002;20:163-173.

73 Amirpour N, Karamali F, Rabiee F, Rezaei L, Esfandiari E, Razavi S, Dehghani A, Razmju $\mathrm{H}$, Nasr-Esfahani MH, Baharvand H: Differentiation of human embryonic stem cell-derived retinal progenitors into retinal cells by Sonic hedgehog and/or retinal pigmented epithelium and transplantation into the subretinal space of sodium iodate-injected rabbits. Stem Cells Dev 2012;21:42-53.

74 Stanzel BV, Liu Z, Somboonthanakij S, Wongsawad W, Brinken R, Eter N, Corneo B, Holz FG, Temple S, Stern JH, Blenkinsop TA: Human RPE stem cells grown into polarized RPE monolayers on a polyester matrix are maintained after grafting into rabbit subretinal space. Stem Cell Reports 2014;2:64-77.

75 Tzameret A, Sher I, Belkin M, Treves AJ, Meir A, Nagler A, Levkovitch-Verbin H, Barshack I, Rosner M, Rotenstreich Y: Transplantation of human bone marrow mesenchymal stem cells as a thin subretinal layer ameliorates retinal degeneration in a rat model of retinal dystrophy. Exp Eye Res 2014;118:135-144.

76 Guan Y, Cui L, Qu Z, Lu L, Wang F, Wu Y, Zhang J, Gao F, Tian H, Xu L, Xu G, Li W, Jin Y, Xu GT: Subretinal transplantation of rat MSCs and erythropoietin gene modified rat
MSCs for protecting and rescuing degenerative retina in rats. Curr Mol Med 2013;13: 1419-1431.

77 Brant Fernandes RA, Koss MJ, Falabella P, Stefanini FR, Maia M, Diniz B, Ribeiro R, Hu Y, Hinton D, Clegg DO, Chader G, Humayun MS: An innovative surgical technique for subretinal transplantation of human embryonic stem cell-derived retinal pigmented epithelium in Yucatan mini pigs: preliminary results. Ophthalmic Surg Lasers Imaging Retina 2016; 47:342-351.

78 Koss MJ, Falabella P, Stefanini FR, Pfister M, Thomas BB, Kashani AH, Brant R, Zhu D, Clegg DO, Hinton DR, Humayun MS: Subretinal implantation of a monolayer of human embryonic stem cell-derived retinal pigment epithelium: a feasibility and safety study in Yucatan minipigs. Graefes Arch Clin Exp Ophthalmol 2016;254:1553-1565.

79 Bainbridge JW, Smith AJ, Barker SS, Robbie S, Henderson R, Balaggan K, Viswanathan A, Holder GE, Stockman A, Tyler N, PetersenJones S, Bhattacharya SS, Thrasher AJ, Fitzke FW, Carter BJ, Rubin GS, Moore AT, Ali RR: Effect of gene therapy on visual function in Leber's congenital amaurosis. N Engl J Med 2008;358:2231-2239.

80 Maguire AM, Simonelli F, Pierce EA, Pugh EN, Jr., Mingozzi F, Bennicelli J, Banfi S, Marshall KA, Testa F, Surace EM, Rossi S, Lyubarsky A, Arruda VR, Konkle B, Stone E, Sun J, Jacobs J, Dell'Osso L, Hertle R, Ma JX, Redmond TM, Zhu X, Hauck B, Zelenaia O, Shindler KS, Maguire MG, Wright JF, Volpe NJ, McDonnell JW, Auricchio A, High KA, Bennett J: Safety and efficacy of gene transfer for Leber's congenital amaurosis. N Engl J Med 2008;358:2240-2248.

81 Maguire AM, High KA, Auricchio A, Wright JF, Pierce EA, Testa F, Mingozzi F, Bennicelli JL, Ying GS, Rossi S, Fulton A, Marshall KA, Banfi S, Chung DC, Morgan JI, Hauck B, Zelenaia O, Zhu X, Raffini L, Coppieters F, De Baere E, Shindler KS, Volpe NJ, Surace EM, Acerra C, Lyubarsky A, Redmond TM, Stone E, Sun J, McDonnell JW, Leroy BP, Simonelli F, Bennett J: Age-dependent effects of RPE65 gene therapy for Leber's congenital amaurosis: a phase 1 dose-escalation trial. Lancet 2009;374:1597-1605.

82 Hauswirth WW, Aleman TS, Kaushal S, Cideciyan AV, Schwartz SB, Wang L, Conlon TJ, Boye SL, Flotte TR, Byrne BJ, Jacobson SG: Treatment of Leber congenital amaurosis due to RPE65 mutations by ocular subretinal injection of adeno-associated virus gene vector: short-term results of a phase I trial. Hum Gene Ther 2008;19:979-990.

83 Rakoczy EP, Lai CM, Magno AL, Wikstrom ME, French MA, Pierce CM, Schwartz SD, Blumenkranz MS, Chalberg TW, Degli-Esposti MA, Constable IJ: Gene therapy with recombinant adeno-associated vectors for neovascular age-related macular degeneration: 1 year follow-up of a phase 1 randomised clinical trial. Lancet 2015;386:2395-2403. 
84 Constable IJ, Pierce CM, Lai CM, Magno AL, Degli-Esposti MA, French MA, McAllister IL, Butler S, Barone SB, Schwartz SD, Blumenkranz MS, Rakoczy EP: Phase 2a aandomized clinical trial: safety and post hoc analysis of subretinal rAAV.sFLT-1 for wet age-related macular degeneration. EBioMedicine 2016; 14:168-175.

85 Schwartz SD, Hubschman JP, Heilwell G, Franco-Cardenas V, Pan CK, Ostrick RM, Mickunas E, Gay R, Klimanskaya I, Lanza R: Embryonic stem cell trials for macular degeneration: a preliminary report. Lancet 2012; 379:713-720.

86 Schwartz SD, Tan G, Hosseini H, Nagiel A: Subretinal transplantation of embryonic stem cell-derived retinal pigment epithelium for the treatment of macular degeneration: an assessment at 4 years. Invest Ophthalmol Vis Sci 2016;57:ORSFc1-9.

87 Leung EH, Flynn HW Jr, Albini TA, Medina CA: Retinal detachment after subretinal stem cell transplantation. Ophthalmic Surg Lasers Imaging Retina 2016;47:600-601.

88 Gaudana R, Jwala J, Boddu SH, Mitra AK: Recent perspectives in ocular drug delivery. Pharm Res 2009;26:1197-1216.

89 Costa RA, Jorge R, Calucci D, Cardillo JA, Melo LA Jr, Scott IU: Intravitreal bevacizumab for choroidal neovascularization caused by AMD (IBeNA Study): results of a phase 1 dose-escalation study. Invest Ophthalmol Vis Sci 2006;47:4569-4578.

90 Moshfeghi DM, Kaiser PK, Scott IU, Sears JE, Benz M, Sinesterra JP, Kaiser RS, Bakri SJ, Maturi RK, Belmont J, Beer PM, Murray TG, Quiroz-Mercado H, Mieler WF: Acute endophthalmitis following intravitreal triamcinolone acetonide injection. Am J Ophthalmol 2003;136:791-796.

91 Ausayakhun S, Yuvaves P, Ngamtiphakom S, Prasitsilp J: Treatment of cytomegalovirus retinitis in AIDS patients with intravitreal ganciclovir. J Med Assoc Thai 2005;88(suppl 9):S15-S20.

92 Stout JT, Francis PJ: Surgical approaches to gene and stem cell therapy for retinal disease. Hum Gene Ther 2011;22:531-535.

93 Kolstad KD, Dalkara D, Guerin K, Visel M, Hoffmann N, Schaffer DV, Flannery JG: Changes in adeno-associated virus-mediated gene delivery in retinal degeneration. Hum Gene Ther 2010;21:571-578.

94 Wert KJ, Skeie JM, Davis RJ, Tsang SH, Mahajan VB: Subretinal injection of gene therapy vectors and stem cells in the perinatal mouse eye. J Vis Exp DOI: 10.3791/4286.
95 Conlon TJ, Deng WT, Erger K, Cossette T, Pang JJ, Ryals R, Clement N, Cleaver B, McDoom I, Boye SE, Peden MC, Sherwood MB, Abernathy CR, Alkuraya FS, Boye SL, Hauswirth WW: Preclinical potency and safety studies of an AAV2-mediated gene therapy vector for the treatment of MERTK associated retinitis pigmentosa. Hum Gene Ther Clin Dev 2013;24:23-28.

96 Wert KJ, Davis RJ, Sancho-Pelluz J, Nishina PM, Tsang SH: Gene therapy provides longterm visual function in a pre-clinical model of retinitis pigmentosa. Hum Mol Genet 2013;22:558-567.

97 Cideciyan AV, Hauswirth WW, Aleman TS, Kaushal S, Schwartz SB, Boye SL, Windsor EA, Conlon TJ, Sumaroka A, Roman AJ, Byrne BJ, Jacobson SG: Vision 1 year after gene therapy for Leber's congenital amaurosis. N Engl J Med 2009;361:725-727.

98 Kay MA, Glorioso JC, Naldini L: Viral vectors for gene therapy: the art of turning infectious agents into vehicles of therapeutics. Nat Med 2001;7:33-40.

99 Li W, Kong F, Li X, Dai X, Liu X, Zheng Q, Wu R, Zhou X, Lu F, Chang B, Li Q, Hauswirth WW, Qu J, Pang JJ: Gene therapy following subretinal AAV5 vector delivery is not affected by a previous intravitreal AAV5 vector administration in the partner eye. Mol Vis 2009; 15:267-275.

100 Li Q, Miller R, Han PY, Pang J, Dinculescu A, Chiodo V, Hauswirth WW: Intraocular route of AAV2 vector administration defines humoral immune response and therapeutic potential. Mol Vis 2008;14:1760-1769.

101 Bloquel C, Bourges JL, Touchard E, Berdugo M, BenEzra D, Behar-Cohen F: Non-viral ocular gene therapy: potential ocular therapeutic avenues. Adv Drug Deliv Rev 2006; 58:1224-1242.

102 Carr AJ, Smart MJ, Ramsden CM, Powner MB, da Cruz L, Coffey PJ: Development of human embryonic stem cell therapies for age-related macular degeneration. Trends Neurosci 2013;36:385-395.

$103 \mathrm{Hu}$ Y, Liu L, Lu B, Zhu D, Ribeiro R, Diniz B, Thomas PB, Ahuja AK, Hinton DR, Tai YC, Hikita ST, Johnson LV, Clegg DO, Thomas BB, Humayun MS: A novel approach for subretinal implantation of ultrathin substrates containing stem cell-derived retinal pigment epithelium monolayer. Ophthalmic Res 2012;48:186-191.
104 Hillenkamp J, Surguch V, Framme C, Gabel VP, Sachs HG: Management of submacular hemorrhage with intravitreal versus subretinal injection of recombinant tissue plasminogen activator. Graefes Arch Clin Exp Ophthalmol 2010;248:5-11.

105 Timmers AM, Zhang H, Squitieri A, Gonzalez-Pola C: Subretinal injections in rodent eyes: effects on electrophysiology and histology of rat retina. Mol Vis 2001;7:131-137.

106 Qi Y, Dai X, Zhang H, He Y, Zhang Y, Han J, Zhu P, Zhang Y, Zheng Q, Li X, Zhao C, Pang J: Trans-corneal subretinal injection in mice and its effect on the function and morphology of the retina. PLoS One 2015;10: e0136523.

107 Schlichtenbrede FC, da Cruz L, Stephens C, Smith AJ, Georgiadis A, Thrasher AJ, Bainbridge JW, Seeliger MW, Ali RR: Long-term evaluation of retinal function in Prph2Rd2/ $\mathrm{Rd} 2$ mice following AAV-mediated gene replacement therapy. J Gene Med 2003;5:757764.

108 Ehlers JP, Petkovsek DS, Yuan A, Singh RP, Srivastava SK: Intrasurgical assessment of subretinal tPA injection for submacular hemorrhage in the PIONEER study utilizing intraoperative OCT. Ophthalmic Surg Lasers Imaging Retina 2015;46:327-332.

109 Pfeffer B, Wiggert B, Lee L, Zonnenberg B, Newsome D, Chader G: The presence of a soluble interphotoreceptor retinol-binding protein (IRBP) in the retinal interphotoreceptor space. J Cell Physiol 1983;117:333341.

110 Gerding H: A new approach towards a minimal invasive retina implant. J Neural Eng 2007;4:S30-S37.

111 Parikh S, Le A, Davenport J, Gorin MB, Nusinowitz S, Matynia A: An alternative and Validated Injection Method for Accessing the Subretinal Space via a Transcleral Posterior Approach. J Vis Exp DOI: 10.3791/ 54808.

112 Nickerson JM, Goodman P, Chrenek MA, Bernal CJ, Berglin L, Redmond TM, Boatright JH: Subretinal delivery and electroporation in pigmented and nonpigmented adult mouse eyes. Methods Mol Biol 2012;884:53-69.

113 Komaromy AM, Varner SE, de Juan E, Acland GM, Aguirre GD: Application of a new subretinal injection device in the dog. Cell Transplant 2006;15:511-519. 